\title{
The Chinese University 3.0 in a Global Age: History, Modernity and Future ${ }^{1}$
}

\author{
Jun Li \\ The University of Hong Kong
}

\begin{abstract}
Some contend that almost all universities follow institutional patterns derived from Western models and that all Asian universities are based on European academic models and traditions. However, the Chinese University 3.0 may be exceptional, demonstrating key characteristics of China's scholarly tradition, though it has been strongly influenced by various Western models over the $20^{\text {th }}$ century. Taking a historical-cultural approach, this chapter constructs the concept of the Chinese University 3.0, investigating its key values and features and possible contributions in a global age. First, the chapter differentiates the three distinct stages of Chinese universities in history and looks into their institutional development and characteristics. Then, it focuses on the Chinese University 3.0 moving toward world-class status and mass higher education by reflecting on such core values and features as self-mastery and intellectual freedom, humanist (zhi-xing) mission and institutional diversity (he'er butong), to demonstrate how they differ culturally from the dominant Anglo-Saxon and American models but shares some commonalities with the continental European and Japanese models of the university. The final section considers policy implications of the emerging Chinese model, its lessons for reform and practice, and its potential role in fostering vibrant democracies and global dialogue among civilizations in the future.
\end{abstract}

Keywords: Chinese University 3.0, higher education, self-mastery, intellectual freedom, humanist mission, institutional diversity, policy

\section{Introduction}

In recent decades, efforts to raise the quality of higher education and nurture world-class universities (WCUs) have grown apace around the globe. Nowhere has this been more evident than in China, and the emerging Chinese University 3.0 is likely to have considerable global influence, given China's rising economic and geo-political importance. While most other societies in East Asia moved to mass higher education systems well before they launched focused efforts to create WCUs, China has taken on both endeavors in addition to internationalization over the same period since the late 1990s.

In this chapter I look first at the historical trajectory of Chinese universities from medieval times to modernity by differentiating it into three macro, distinct stages, i.e., Chinese Universities 1.0, 2.0 and 3.0. Then, I reflect on the core values and features of the emerging Chinese University 3.0, such as self-mastery and intellectual freedom, humanist (zhi-xing) mission and institutional diversity (he'er butong), and identify the ways it differs culturally from the dominant Anglo-American model, while sharing some commonalities with the

\footnotetext{
${ }^{1}$ This chapter is developed from my following journal article with the permission from Springer: Li, J. (2012). World-class higher education and the emerging Chinese model of the university. Prospects: Quarterly Review of Comparative Education, 42(3), 319-339.
} 
continental European and Japanese models of the university. Finally, I consider the policy implications of the emerging Chinese University 3.0, its implications for higher education reform and development, and its potential role in fostering vibrant democracies and global dialogue among civilizations in the future.

The Chinese University 3.0 is an inclusive term that refers to the latest developmental stage of Chinese universities with emerging features, comparatively speaking with its earliest and later forms represented respectively by the ancient Chinese University 1.0 and the modern Chinese University 2.0. The idea itself is not new at all to differentiating the developmental stages of Chinese universities, but these new concepts can better capture and be more focused on the distinct features of Chinese universities in each of the three stages over time, especially from a macro, historical and cultural lens.

\section{The Chinese University 1.0}

The Chinese University 1.0 can be traced back to the $12^{\text {th }}-8^{\text {th }}$ century BCE, when such higher institutes as the Piyiong and Pangong were constantly established (Sun, 2009, pp. 19-20). The Taixue (Confucian Institute) was the first imperial university institutionally created for political reasons in the Han Dynasty in 124BCE (Sun, 2009, pp. 109-110), one thousand years earlier than the Al-Azhar University opened in 970 in Egypt and the University of Bologna in 1088 in Italy that both were created for religious purposes and are widely viewed as two of the oldest universities in the world. The Taixue heritage was carried forward in the following dynasties in China over two thousand years until the collapse of the Qing Empire (1644-1912), and was developed into various forms in history, such as the Guozixue in the Western Jin Dynasty (265-313), the Guozisi in the Northern Qi Dynasty (550-577) or the Guozijian in the Song Dynasty (960-1056). In addition to the institutionalized imperial university system, there were other specialized imperial institutes, such as the Shuxue (Institute of Calligraphies), the Suanxue (Institute of Mathematics), the Wuxue (Institute of Martial Arts), the Yixue (Institute of Medicine) and the Lüxue (Institute of Laws), coupled with the civil servant examination system $(k e j u)$. The imperial universities were not only the higher education institutions in China's medieval times, but some of them, e.g., the Taixue and Guozijian, served as the state administrative department of education, equivalent to the ministry of education nowadays. The dual role of the Taixue system made the imperial universities institutionally integrated with the state system, and such a tradition is stilled carried on in other forms in modern China, such as the Presidential Responsibility System under the Guidance of the Communist Party.

At the same time, private higher education institutions co-existed in parallel with the Taixue (and Guozijian) system in China's medieval history. At the very beginning, the Jixia Academy was established by Duke Huan in the state of Qi in the third century BCE, an institution that met all three characters of Studium Generale, the earliest form of Western universities: geographically open, systematically higher and multiple-disciplinary education (Rashdall 1895, vol 1, p. 9). At one time it had a community of more than ten thousand students and teachers. While it was an imperial higher institution financially sponsored by the state of Qi, it was effectively autonomous, and provided space hosting many private schools to debate with and learn from each other, without any intervention from government. It was self-governed, with teachers and students who adhered respectively to the Confucian School, the Taoist School, the Huanglao School, the Yinyang School and others. Students and teachers came and went as they pleased, and the teaching was open to all, regardless of their academic background. Regular forums were held where teachers and students of different schools could debate with each other or hold discussions (Li 1988; Needham 1954, pp. 95-96; Twitchett and Faribank 1986, p. 73). 
Later in the eighth century during the late Tang dynasty, the mainly autonomous Shuyuan (academies) came into being as a unique type of private higher education institution in Chinese history (Li, Wang and Li 1994, pp. 9-17). They are widely seen as inheritors of the spirit of the Jixia Academy, and some of them were modelled from Buddhist or Taoist temples that focused on scripts studies in unique forms of meetings and procedures ( $\mathrm{Li} 1994$, pp. 449-453; Li, Wang and Li 1994, pp. 140-167), somewhat like the origin of cathedral schools before the rise of Western universities in mediaeval Europe (Jaeger, 2000). They were set up by scholars to provide an autonomous learning environment where students could engage in study without intervention from government. Over its history of 1,200 years, the Shuyuan accumulated significant experience in organizational governance, curricular design and approaches, ways of integrating knowledge and practice, and a unique style of relationship between students and teachers. Together with the imperial university system, the Shuyuan made the tradition of the Chinese University 1.0 very dynamic and diverse, combined with both public and private, and both comprehensive and specialized types of higher education institutions, which core curricula were centered on political ethics and inclusive of other learning contents (Lenzen 2015).

\section{The Chinese University 2.0}

The Chinese University 2.0 came into existence in the late $19^{\text {th }}$ century, and again for political reasons. The collapsing late Qing Empire tried to revive its regime with various reforms, such as the Self-Strengthening Movement (1861-1895), the Hundred Days' Reform (1898) and the New Reform (1901-1911). These political reforms consistently sought to develop new, practical talent as opposed to revitalizing the traditional Confucian intelligentsia. Subsequently, it became widely accepted that renovating the old education system and establishing modern universities were vital and urgent tasks. With a strong catchup mentality under the semi-colonialism, ${ }^{2}$ a number of politicians and educators agreed that modern universities adopted from the Western models were crucial for meeting the political goals of national survival and self-strengthening. Thanks to these political efforts, the Chinese University 2.0 was formed since 1895, when the Zhongxi Xuetang (School for Chinese and Western Studies) was opened in Tianjin by Sheng Xuanhuai (1844-1916) as the first modern university in China.

The Chinese University 2.0 has experienced various stages of modernity over the past century up to the last 1990s. For example, Hayhoe (1996) differentiates its development into at least three stages, i.e., the Nationalist Period (1911-1949), the Socialist Period (19491978) and the Reform Period (1978-1990), each accompanying a radical socio-political and cultural transformation in China. But if the very initial beginning of Chinese University 2.0 is included, there should have the following three stages: Establishment (1895-1911), Experimentation (1911-1949) and Institutionalization (1949-1998).

The initial Establishment Period occurred when the late Qing Dynasty was struggling for its survival against Western imperialism and colonialism, so almost all universities opened that time were for political purposes and emulated from the West through Japan. The Experimentation Period saw the contradictions in the integration of Western values of institutional autonomy and academic freedom, mainly from Germany and the U.S., into the Chinese way of higher education and its relation with the state (Hayhoe 1996). Various Western models, such as the American, the British, the German, the French and the Japanese, were all tried out by some individual institutions or nationwide. Meanwhile, the

\footnotetext{
${ }^{2}$ Although China was never completely colonized in the $19^{\text {th }}$ and $20^{\text {th }}$ centuries, many of its parts, such as Hong Kong, Macao and Taiwan, alongside some parts in Shanghai, Shandong Province and in the Northeast, were colonized by Japan, France, Germany, Portugal or the U.K.
} 
independence of higher education in terms of institutional governance was appealed strongly in this stage, minimizing the unwanted intervention from the state ( $\mathrm{Li}$ 1998, pp. 286-299). The Institutionalization Period was dominated by socialist ideology in the restoration, setback and development of higher education between 1949 and 1998, and the Soviet Union model used to have a profound part in this process of modernity. Furthermore, the proletarian dictatorship controlled universities in Mainland China during the Cultural Revolution (1966-1976). After progressive leaders such as Deng Xiaoping had taken over the political power of China, the Chinese government adopted a reform and open door policy in 1978 in order to modernize the country, Chinese universities were able to recover and entered a period of continuous modernity up to 1998, when the then President Jiang Zemin announced his ambitious plan to build WCUs (Jiang 1998). Although the Chinese University 2.0 was predominant by Western models of the university, the role of the state and its sociopolitical mission and institutional diversity were both constantly and explicitly observable throughout its various stages. However, it has been challenged by the intensifying process of globalization, led with the WCU movement, in which symbolic relevance and cultural values become central concerns (Elman 2000).

\section{The New Era of the Chinese University 3.0}

The emergence of the Chinese University 3.0, which has started roughly from the late 1990s, as a result of both China's unprecedented quest for WCUs and revolutionary massification of higher education system. The Chinese University 3.0 is unusual in the fact that it has taken on WCUs, massification and internationalization over the same decade since the late 1990s. A closer examination of the triple processes and their symbolic and cultural impact enables a more comprehensive understanding of these phenomena and their policy implications.

\section{The Ideological Rationale}

There are several national ideologies that have served as the driving forces for China's changing landscape of higher education in general and the emerging Chinese University 3.0 in particular. First and foremost, higher education has been traditionally valued in China as a key instrument for individual and national development, first elaborated by classical Confucianism (Li 1998; Li and Hayhoe 2012). Such a Confucian value becomes emergent and more prominent for China in the new context of globalization.

Second, the Chinese had been always proud of their long civilization and national achievement, but in the $19^{\text {th }}-20^{\text {th }}$ centuries China lagged behind Western emerging superpowers, which colonized Hong Kong, Macao and Taiwan and some of territories in Northeastern provinces, Shanghai, Tianjin and Shandon, etc. To fight for its revitalization, especially against the Japanese invasion in the 1930s-1940s, China developed a strong mentality of catch-up and global competitiveness, which has served as a state-led, collectively recognized ideology for national survival and modernity under the accelerating pressure of colonialism and globalization. Additionally, China's quest for WCUs and massification of higher education has served as convenient political tools, supported by modernization theory and human capital theory.

\section{The WCU Movement}

The most notable agendas of building WCUs include Projects 211 and 985. In 1993, Project 211 was placed on the national policy table in the Guidelines for the Reform and Development of Education in China (The Communist Party of China Central Committee [CPCCC] and the State Council 1993). Formally starting in 1995, this national initiative 
aims to improve the quality of teaching, research and administration of universities, and make some of them world-class. It provides developmental support in three major areas: overall infrastructure and faculty in selected institutions, meaning funding for both hardware and software; key disciplinary areas in a wider range of institutions that respond to the demands of socioeconomic development; and public service systems such as the development of national data bases for education and research. The project has set up special funds to use solely for its tasks, and universities are encouraged to first apply for participation by submitting a plan that is rigorously evaluated. By 2011, the project had finished three phases (1996-2000, 2001-2006 and 2007-2011), with a total of 112 universities and 821 key disciplines selected, three national public service systems constructed, and the fourth phase (2012-present) is still underway.

Few years later the Chinese government launched Project 985, on the occasion of Peking University's centennial celebration in May 1998, as reflected in the project title. The Action Plan for Educational Revitalization in the $21^{\text {st }}$ Century (MOE 1998) laid out a straightforward pathway to build a few WCUs and world-class academic programs by the 2010s. Its first phase was implemented from 1999 to 2004; the original nine institutions grew to a total of 34. Peking and Tsinghua Universities received a total of 280 million US dollars; the others received less national funding, but benefited from revenue and support from their municipal or provincial governments. The second phase began in 2004, with five more universities finding their way into the elite club. Project 985's strategy is to facilitate a great leap forward in building a limited number of world-class universities, with a huge public investment from both the central and local governments.

Most recently, Projects 211 and 985 have been streamlined by a comprehensive, national master plan for a new wave of the WCU movement. The Master Promotion Plan of Building World-class Universities and Disciplines promulgated by the State Council (2015) aims to ambitiously build China as a superpower in higher education with sufficient top universities and disciplines in the world by the mid- $21^{\text {st }}$ century. More importantly, China has constantly committed to its own cultural heritage of higher education for these national initiatives, as shown in the new Master Promotion Plan of Building WCUs in 2015.

The 2015 Academic Ranking of World Universities by Shanghai Jiaotong University shows that there are seven Chinese universities ranked in the top 200 world universities, while none of them was enlisted ten years ago. Additionally, mainland universities have been continuously moving up their ranks in the Greater China Region (Hong Kong, Macao, Mainland and Taiwan) over the past four years since 201, according to the same Shanghai Jiaotong Ranking. More importantly, the research capacity of Chinese universities has grown remarkably. For example, China's world share of SSCI publications has increased from $0.01 \%$ in 1978 to $0.67 \%$ in 2007 , with more than half of them were published in the past decade (Liu and Liu 2009), mainly due to the accelerated investment in terms of funding and staffing in Chinese universities.

\section{The Massification Initiative}

Coupled with Projects 211 and 985, China has also started the radical massification process of its higher education system since the late 1990s, which has made the country "the largest national higher education system in the world" since 2003 (The UNESCO, 2003, June 2325, p. 8). The total enrollment of students in higher education institutions jumped from 3.6 million in 1991 to 34.6 million in 2013, and the gross enrollment rate increased from 3.5 percent in 1991 to 34.5 percent in 2013 (MOE, 1992, 2014). The massification of higher education in China, spurred in 1999, is both revolutionary and unprecedented in the history of Chinese universities and their modern transformations. 
In 1991 only $3.5 \%$ of the relevant age group between 18 and 22 benefited from any form of higher education in China. This percentage reached $7.2 \%$ in $1995,10.5 \%$ in 1999 , and around $37.5 \%$ in 2014 with 35.6 million students enrolled. The average institutional size of regular higher education institutions has almost quadrupled from 2,381 students in 1993 to 9,995 students in 2014. These outcomes are incredible achievements for a country like China that has the largest population in the world. In addition, after decades of closedown and re-entry into the higher education scene in the early 1980s, private higher education institutions have been growing rapidly since the late 1990s. In 2004, the Ministry of Education (MOE) started to publicize national data for private higher education institutions. According to the MOE's Annual Statistical Communiqué 2003-2014, Minban colleges and universities increased from 173 in 2003 to 728 in 2014, enrolling a total number of 5.9 million students.

\section{The Internationalization Agenda}

Alongside the two initiatives mentioned earlier, Chinese universities have also endeavored to rapidly internationalize themselves in multiple ways. By 2012, there were a total of 328,330 international students from 200 countries and regions studying in Chinese universities (The Editorial Board of the People's Republic of China Yearbook 1999, p. 640), $662 \%$ from 4,3084 from 164 countries and regions in 1998 (The Editorial Board of the People's Republic of China Yearbook 1999, p. 1085).

An excellent example is the rapid spread of the Confucius Institutes (CIs) and Classrooms (CCs) around the world. A demand-led response modality had enabled hundreds of Chinese universities, many enlisted in Project 211 or 985, to partner with their global counterparts to set up the CIs and CCs worldwide, the largest project of international collaboration in language and cultural exchange in human history. Within just one decade, $500 \mathrm{CIs}$ were opened in 125 countries and areas, with 46 in Africa, 110 in Asia, 169 in Europe, 18 in Oceania and 157 in the Americas, registering over 1.9 million local learners by the end of 2015 (Hanban n.d.). The new way of the collaboration with their overseas partners through CIs is a milestone to Chinese universities, which signals that they are in an unparalleled stage that goes global in real sense (Li and Tian 2015).

\section{Core Values and Features of the Chinese University 3.0}

The initial outcomes of these national endeavors appear very positive, having raised universities' overall quality while expanded their size and outreach, as evidenced recently in the large-scale studies on China's move to mass higher education (Hayhoe, Li, Lin and Zha 2011) and on China's rising research universities (Rhoads, Wang, Shi and Chang 2014). They signal the emergence of the Chinese University 3.0 from its earlier versions. There are at least four core values and features that are evident at this stage: self-mastery, intellectual freedom, humanist (zhi-xing) mission and institutional diversity (he'er butong), as discussed in the following, if reflected from a macro, historical and cultural lens on the trajectory and ongoing development of Chinese universities. I will use Weber's (1948) concept of the ideal type to identify these core values and features in contrast to those that are traditional to Western universities.

\section{Self-Mastery and Intellectual Freedom}

The English historian Hastings Rashdall (1895) observed that the twin characteristics of institutional autonomy and academic freedom were the key to the medieval universities in Europe. In her widely cited volume, Hayhoe (1996) argues that none of them fits the Chinese context and that "there was no institution in Chinese tradition that could accurately be called 
a university" (p. 10). China's classical scholarly institutions never had the full protection of a legal charter or the right to own property, rather they were an arm of the imperial bureaucracy, which administered the civil service examinations and selected the most knowledgeable and talented scholars to serve as officials. At the opposite pole were private academies in remote rural areas which enjoyed considerable autonomy but were not protected by law and were sometimes co-opted into imperial service. She then proposes that the terms "self-mastery" and "intellectual freedom" in the Chinese context may be seen as parallel concepts to autonomy and academic freedom in Western tradition (Hayhoe 1996; 2001).

The fundamental difference of higher education institutions between the West and China, represented in parallel by autonomy and self-mastery, and academic freedom and intellectual freedom, is largely due to their contrasting origins with dissimilar cultural and epistemological traditions, which will be detailed later in this chapter. Briefly here, Western universities have original roots in churches in medieval times and their main activities of teaching and learning were focused initially for religious purposes. Quite differently, Chinese universities were established at the very beginning in history for political purposes, and they were set up and constructed primarily to serve, and oftentimes to guide, state interests. Such a dichotomous nature of the two types has shaped their historical development fundamentally and distinctly, in terms of institutional mission, educational and learning process, curriculum and standards, teacher-student relationships, etc. It has made Chinese universities never a true Western concept of the "university", though nowadays the Western concept is widely accepted and used to refer to Chinese universities.

In striking contrast with the tradition of autonomy in Western universities, and highly related to its own tradition, the Chinese University 3.0 has demonstrated a closer, more integrated relationship with the government. It has served and supported the state's interests in every way possible, including cultivating scholar-officials for political leadership and catering for national projects. It is more receptive and responsive to government initiative and intervention, and lacks autonomy in the Western sense. At the same time it has been highly responsible for its own survival and development, in terms of its internal administration. Thus the term self-mastery captures the spirit of the institution better than autonomy, a concept that conveys a sense of political or legal independence in Chinese (Hayhoe 2001; Hayhoe and Zhong 2001). Illustrating this self-mastery are the initiatives of individual scholars and institutions that stimulated the national drive to reach world-class status ( $\mathrm{Li}$ 2012). On another level, the self-mastery of the Chinese University 3.0 may have some parallels with China's stance on self-determination, one of the three theorems in the Beijing Consensus which Ramo (2004) has related to the Chinese development model.

On the other hand, traditional Chinese scholar-officials probably had a higher degree of intellectual authority than was seen in Europe, including the right to admonish the Emperor himself. Meanwhile, scholars who withdrew from government and founded private academies exercised an intellectual freedom that went beyond the parameters of the theoretical and specialist academic knowledge associated with the concept of academic freedom in $19^{\text {th }}$ century Europe. They had a very high sense of both moral and sociopolitical responsibilities, and they believed the most valued knowledge could only be fully demonstrated in its application to personal and social actions for the highest public good. It contrasts with Newman's great idea of "knowledge as its own end" as the first principle of the university (Newman, 1859, pp. 99-123).

Today, universities are controlled, both directly and indirectly, by the state (government) or the market, or both, like the American multiversities (Kerr 1963), the Japanese public universities (Kaneko 2009), and the Chinese University 3.0. Perhaps the question of greatest 
interest here is which model better lends itself to the creation of WCUs, and which can better stand up to the negative pressures coming from globalization of nothing (Ritzer 2003). Some scholars contend that almost all universities follow institutional patterns derived from Western models (Altbach 1992) and that all Asian universities are based on European academic models and traditions (Altbach and Selvaratnam 1989). These assertions are echoed by some Chinese scholars who deny the continued influence of ancient Chinese institutions (Ding 2001; 2004). However, the Chinese University 3.0 may be exceptional, demonstrating that it reflects persisting characteristics of China's scholarly tradition, though it has been strongly influenced by various Western models over the $20^{\text {th }}$ century.

\section{Humanist (Zhi-Xing) Mission}

The Chinese University 3.0 owes to its predecessors that were centered on Confucian ethics - Zhi-Xing, a third core value and feature of the Chinese University 3.0. The Zhi-Xing or humanist mission of higher education and learning is deeply shaped by Confucian epistemology and Chinese ways of higher learning and education:

Therefore, the way of higher learning is to cultivate people and to nurture their ways of life, converting those close by gracefully and winning over those at a distance. (Xueji n.d., 5) ${ }^{3}$

Wang Yangming (1472-1529), a neo-Confucian in the Ming dynasty (1368-1628), explicitly proposed Zhi-Xing Heyi (Wang, n.d., p. 3) during his directorship of the well-known Guiyang Shuyuan. Zhi literally refers to (ethical) knowing or learning, Xing means (ethical) doing or practicing, and Heyi dictates their oneness:

Knowing is the genesis of doing, and doing is the corollary of knowing: Learning to be a sage has only one Kungfu - knowing and doing is one instead of two that can be separated. (Wang n.d., p. 9)

It must be noted that the purpose of both Zhi and Xing lies in Confucian humanism: "to let one's innate virtue shine forth, to renew the people, and to rest in the highest good" (The Great Learning n.d., 1.1). Through the interwoven Eight Steps of Learning (The Great Learning n.d., 1.5), the Zhi-Xing mission begins with the investigation of things and extension of knowledge, goes through self-cultivation of personhood and the care of family, and ends up with the governance of the state and the making of a peaceful world for all people, all centered on the cultivation of individual morality for social development ( $\mathrm{Li}$ and Hayhoe 2012). These Eight Steps are not exclusive to investigation into the natural world, but actually base the interactive and progressive process of higher learning and education first on the exploration of nature and the self, which are then expanded into moral perfection in terms of the growth of personhood, deontological capacity and ethical wisdom for a benevolent, free and equitable social world (Li 2015).

\footnotetext{
${ }^{3}$ Xueji (The Theory of Education) is a classical Confucian essay from Liji (The Book of Rites) compiled two thousand years ago. The translation here is mainly mine, with adaptations from the following references: Chai, C., \& Chai, W. (1965, trans. \& eds.). The humanist way in ancient China: Essential works of Confucianism. New York: Bantam Books, Inc.; Gao, S. L. (2005). Xueji yanjiu [A study of Xueji]. Beijing: People's Education Press; Gao, S. L. (1982). Xueji pingzhu [An annotation of Xueji]. Beijing: People's Education Press; Wong, W. S. (1976). The Hsüeh Chi, an old Chinese document on education. History of Education Quarterly, 16 (2), 187-193; and Xu, D., \& McEwan, H. (2016). Universal principles for teaching and learning: Xue Ji in the 21st century. Albany, NY: SUNY Press.
} 
The humanistic orientation of Confucian higher learning and education has been carried forward to modern times by later Confucian scholars such as Ch'ien Mu (1895-1990), who anticipated a new Chinese model of the university. In his popular article on The Ideal of the University, Ch'ien (1943) criticized the popularity of commercial and Western orientations of university education in China driven by capitalism and colonialism, and advocated humanistic emancipation through forms of higher education that stimulated Confucian ethics. His pursuit of moral cultivation has been carried on by his disciples (Yu, 1974), and the Chinese University 3.0 continues to practice such a humanistic value with the rapid spread of Confucius Institutes all over the world. This Confucian value and feature was put forward two thousand years ago, and so fundamentally shaped contemporary Chinese universities that they are typified as the Confucian or post-Confucian model (Marginson 2011, 2013). ${ }^{4}$

In the European context, academic freedom has generally been associated with theoretical and specialist fields of knowledge, allowing for absolute freedom in the search for understanding in the natural and social worlds, but less freedom in the application of that understanding to political or social activism. By contrast, intellectual freedom of the Chinese University 3.0 is deeply rooted in China's epistemological traditions, which maintained a commitment to a certain holism in knowing, and insisted on the demonstration of truth in socio-political action, rather than through logical argumentation or experimentation. Confucius believed that knowledge is to be used for ethical, moral and political purposes, with the application moving from personal cultivation, to family and social relationships, and to socio-political action (Chen 1990; Li 1998, 2009; Li and Hayhoe 2012), rather than to support the exploration of scientific facts or religious beliefs. Since the Chinese University 1.0, this tradition of integrating ethics-centered knowing into social practice, or the unity of knowing (knowledge) and action, has been incorporated into the humanist mission of Chinese universities. From classroom learning to social applications, the Four Books and Five Classics formed the core contents for China's civil service examinations (Hayhoe and $\mathrm{Li}$ 2010). Knowledge about arithmetic, geometry, logic, engineering, agriculture, and law was well developed and applied in a range of state projects, yet it did not form the core of the curriculum, as did the trivium and quadrivium in medieval European universities.

In medieval Europe, theology was viewed as "queen of the sciences", responsible for guiding all other fields of knowledge, but the Chinese had no clear hierarchy among subject areas. Rather, all knowledge was viewed as pragmatic, and non-religious, focused on political ethics. In Europe, the Kantian distinction between facts and values liberated the sciences and social sciences from theological restrictions, facilitating the academic freedom that has characterized modern Western universities, but China developed quite differently. Chinese epistemology fostered a situation where scholars have chosen either the intellectual authority accorded to them in their role as scholar officials, or the intellectual freedom they could gain through periods of withdrawal into the private world of the family or local academy. The fact that knowledge must always be demonstrated in action for the public good has often led scholars to face dangers, particularly in periods of national decline or social conflict, when they were likely to contradict those in power.

It is worth noting that the Chinese tradition of written civil service examinations to select an elite to rule, and the idea of integrating higher education institutions within the imperial bureaucracy, were admired by European Jesuits and philosophers like Voltaire and Leibniz.

\footnotetext{
${ }^{4}$ The term of Confucian or post-Confucian model is excellent in capturing the core feature of Chinese universities, but it seems inapplicable to fully reflect the bigger picture of the Chinese University 3.0 which is more inclusive in a global age.
} 
How much did these values influence the emergence of what Clark (1983) calls the "continental model" of the university and what Neave (2001) terms the "Roman model" in $18^{\text {th }}$ century Europe? Researchers have not answered this question. Still, the parallels with Chinese traditional patterns are obvious: higher education systems that are part of a modern state apparatus, with professors as civil servants, and autonomy protected by the concept of legal homogeneity, rather than legal personhood or the university's ownership of property. Academic freedom, by contrast, has remained tied to epistemological traditions of rationalism in the European context, while American pragmatism has spawned a somewhat broader concept, more closely allied to the notion of intellectual freedom in the Chinese context (Hayhoe 2001, pp. 331-336).

\section{Institutional Diversity (He'er Butong)}

The Chinese University 3.0 carries its earlier tradition in actively engaging in ambitious projects of the state and controlled by the government. Furthermore, Chinese universities have tended to be highly hierarchical, stratified, and meritocratic, with only a few outstanding public universities at the top, like the Chinese University 1.0 in ancient China. Institutional hierarchy and stratification have also been widely observed in other Confucian heritage societies, including Japan, Korea, Taiwan, and Singapore, where the top research universities are likely to be public with global standing.

Despite being hierarchical, stratified and meritocratic, the Chinese University 3.0 inherits from its predecessors and continues to develop itself as an open, diverse system, which is hybridized with and diversified by the Chinese University 1.0 and 2.0, and Western models (including the Soviet model). As mentioned earlier, the Chinese University 1.0 was a system inclusive to various types of higher education institutions, structured by both public and private, and both comprehensive and specialized. In terms of curricular design, Confucian classics were never the sole source of learning, and arts, Buddhism, Taoism, mathematics, martial arts, medicine, laws and even natural sciences were all among them (Sun 2009).

Comparatively speaking, the Chinese University 2.0 demonstrated even more institutional diversity in terms of the new addition of Christian universities represented by Aurora University (1903) in Shanghai and the Catholic University of Peking (1925), both established by Father Joseph Ma Xiangbo (Hayhoe 1996), and such well-known institutions as Yenching University (1919) in Peiping and St. John's University (1879) in Shanghai (Li, 2014; Lutz, 1971). Christian universities have by nature introduced and embodied Western models of higher education in the greater China region, in terms of institutional autonomy and governance, curriculum, standards and assessment, financing, approaches to pedagogy and campus lifestyle. They also promoted a diverse scholarly culture that embraced religion, the humanities, the social sciences and the sciences (Li 2014).

The institutional diversity has been a Confucian value of higher education, as Confucius always placed importance to harmony with diversity and tolerance as He'er Butong (The Analects of Confucius n.d., 13.23). The Confucian idea was further developed later as "all things being nourished together without hurting one another" and "all courses being pursued without being conflictual or mutually exclusive" by The Doctrine of the Mean (n.d., 30.3), one of the cornerstones of the Chinese University 1.0. It is in this sense that institutional diversity should be able to respect, include, encourage and actualize a vast variety of pedagogical and spiritual beliefs and traditions, institutional forms and endeavors, as well as student backgrounds being favorable to the promotion of inter-cultural and cross-national understanding in a global age. These traditions have been continuously carried forward by the Chinese University 2.0. 
In recent years, the Chinese government has started to re-work on its financing strategies for more even distribution of funding sources to all its institutions. In spite of the many mergers in the 1990s, the system has remained diverse, with polytechnic, normal, agricultural, vocational and religious institutions maintaining their identity and contributions, many vocationally-oriented institutions at the provincial and local level, and an increasing number of private universities that respond directly to social demand of higher learning. Additionally, the internationalization of Chinese universities, represented by the two-way flow of students and faculty going abroad and to China and the rapidly spread international collaborations through Confucius Institutes all over the world since 2004, has vividly manifested the wide impact of institutional diversity in the global age.

\section{Implications for Future}

That the emerging Chinese University 3.0 is clearly characterized by its close connection to government, almost as a state facility or a part of governmental organization, suggests both advantages and disadvantages for its institutional development. This can be seen in China's drive to create WCUs, and the Chinese experience may shed some light on the worldwide movement to build WCUs.

First, it is interesting to note that the classical, fundamental Chinese principle that all things being nourished together without hurting one another and that all courses being pursued without being conflictual or mutually exclusive (The Doctrine of the Mean n.d., 30.3) is reflected in the preservation of He'er Butong in the Chinese University 3.0 - rather than the homogenization around the model of the global research university that dominates the Anglo-American world of higher education. After a decade of massive massification and major support to create top institutions, the Chinese system has been open and diverse, maintaining its various types and levels of institutions and continuing to learn from other models (Hayhoe and Li 2012), mainly from those in Type A. The Chinese University 2.0 has evolved across the $20^{\text {th }}$ century, absorbing influences from the Japanese model in the 1890s, the European model in the 1910s, the American model in the 1920s, and the Soviet model in the 1950s (Hayhoe 1996). Beginning in the early 1980s, it faced marketization and privatization paved by neo-liberal ideology, and has begun to build its global status from the late 1990s. Since then, the Chinese University 3.0 has probably experienced the best period of development in its entire modern history, in terms of national priority incentives and alternative global sources. It has an openness originating from the Confucian philosophical principle and pragmatism to learn from other models around the world, through trial and error, and its top echelon has the resources to develop world-class standards in teaching, research, and governance, to support China's rise in the $21^{\text {st }}$ century.

On the other hand, the Chinese University 3.0 has maintained its institutional identity as an important part of the state system, even though the Higher Education Law of 1998 guarantees its status as a legal person. Independence is expressed in the initiatives of leaders and scholars who make specific choices for their institutions in terms of research orientation, curricular focus, or partner for merger. They do not see this as a matter of detaching themselves from the state, rather as seeking to serve the nation in ways that go beyond the limited vision of their political masters. Thus the concept of self-mastery encapsulates its spirit better than autonomy or independence.

As for intellectual freedom, there are clear limitations on how far university scholars can go in criticizing their government. However, they will never be satisfied with a freedom that is associated only with pure theory or highly specialist knowledge. Rather, Chinese scholars and university leaders tend to have a strong sense of Zhi-Xing mission, and a conviction that knowledge must be expressed in social action, even when that action may be judged as 
politically unacceptable in a particular time or place. By the same token, the action may be oriented towards supporting major state projects, such as the Opto-electronics Lab in Wuhan and its nearby Optics Valley (Hayhoe, Li, Chen and Zhou, 2011, pp. 307-343).

With a governance pattern that is called the Presidential Responsibility System under the Guidance of the Communist Party, the CPC maintains close control over university faculty and student activities. Still, the fact that most universities derive more than half their income from student fees, research, and consulting demonstrates the strong demand for accountability from students, faculty, and the wider community. Thus a civil society is beginning to assert itself, and it will be interesting to watch how this influences the national political system, given that nearly $35 \%$ of young people are now involved in higher education. Nevertheless, the Chinese University 3.0 still has a lower level of intellectual freedom than its Japanese counterpart, and probably less autonomy, though that the Japanese university gained legal person status only in 2004.

Second, while the Chinese government has played a dominant role in providing for the building of WCUs, public resources have been mobilized and distributed quite effectively. This has enabled a few elite institutions to participate actively in the global community, while the huge demands for massification are absorbed by lower-level institutions that prepare students for the local or regional job market. This is probably the best strategy for a developing country with limited resources but a strong dynastic tradition. The highly centralized nature of the Chinese regime, coupled with a meritocratic ethos which has led the CPC to search for outstanding talent to fill senior government positions at all levels, has made implementation fairly smooth. The Chinese approach of neo-authoritarianism has demonstrated that modernization is possible through authoritarian rule (Petracca and Xiong 1990). But how long this form can be sustainable and support China's rise on the global stage is an open question, as argued in a recent book by a group of Chinese scholars (Pan 2009). Though the Chinese development model probably cannot be replicated elsewhere (Ramo 2004), China's experience in the quest for WCUs may be a valuable reference point for developing countries seeking to improve their global status.

Third, it is important to remember that in addition to the drive to develop WCUs, China has also had a massification initiative which has radically expanded higher education provision since the late 1990s. That is very different from places like South Korea, Japan, and Taiwan, where massification occurred earlier, and was followed only recently by projects such as "Brain Korea" and the corporatization of Japanese imperial universities. China has adopted a two-pronged ideology of development, with neo-authoritarianism for political control (Huntington 1991) and neo-liberalism as a pragmatic route to decentralization and marketization. While the convergence of these two discourses makes for some conflicts and contradictions, the economic returns from the rapid massification of higher education, with the highest student fees in the lower vocational and private programmes, have greatly benefited individual institutions. This means that the budget for building WCUs can be prioritized for just a few top research institutions. At the same time, the expanded higher education system has also protected He'er Butong and nurtured alternative types of institutions at various levels, such as normal, agricultural, and polytechnic universities in addition to the comprehensive universities that come closest to the international model of a global research university.

Finally, the efforts of the Chinese University 3.0 have been fraught with contradictions, challenges, and threats. One widely observed problem is that quality has been sacrificed to the massification process, even in some elite institutions. Another serious concern is about academic corruption in Chinese universities. It has obvious negative effects on a society, leading to the deterioration of professional skills and achievement motivation, economic 
and ethical losses, and social inequality (Weidman and Enkhjargal 2008). Unfortunately, since the 1990s there is clear evidence of misconduct in various forms, e.g., false qualifications and achievements, manipulating research data, and academic plagiarism. China has increasingly adopted an instrumentalist, quantified approach to evaluating individual or institutional performance in education and research, with even greater intensity than elsewhere. Those universities listed in Project 211 or 985 face greatest pressures - both management and the public expect faster academic deliverables and other outputs (Li 2016a) - and some scholars compromise to find shortcuts to survival and promotion. It will be interesting to see how China can benefit from the experience of societies such as the United States, Hong Kong, and Singapore, where effective mechanisms have been established to curb corruption.

The third threat is from the officialdom-centered style of administration that is entrenched in some Chinese universities, an offshoot of China's bureaucratic system that traditionally gave priority to government officials (Li 2016b). Thus, political games have been common among individuals and institutions. Given this cultural tradition, leaders and administrators in Chinese universities are viewed as having a higher or more authoritative status on campus, and tend to enjoy a range of economic and political privileges. Professors and students are often in disadvantaged positions, having to struggle for respect and status by taking up official positions themselves. On the other hand, university presidents and top scientists must also bow to their senior leaders and administrators at the provincial bureau or the national Ministry of Education for survival and promotion. An article in Science (Shi and Rao 2010) showed how a few top bureaucrats and their favorite researchers manipulate or "secretly trade" funding for research under the table. The officialdom-centered bureaucracy poses serious challenges for the Chinese University 3.0, since it easily falls prey to corruption, nepotism, favouritism, and hierarchism. In its most recent national guidelines for educational reform and development, the State Council (2010) formally placed debureaucratization, de-policalization, and deregulation on the government agenda as the right direction to solve this chronic problem.

\section{Conclusion}

In conceptualizing WCUs, massification and internationalization of higher education system, the Chinese have shown themselves to be open to learning from attractive features of the historically dominant Western models of the university, but indigenous views on scholarship and scholarly institutions remain strong. The Chinese government has also been open to considering various approaches to the latest development of its higher education system, which can be conceptualized as the Chinese University 3.0. Thus China's experience has shown that a strong state with a developmental agenda can make excellent use of universities to enhance its national position in the global arena, without necessarily imposing a national or globally homogenized format on them. Along with China's rise as a global superpower, the Chinese University 3.0 is emerging, as open, diverse and dynamic institutions, seeking excellence in knowledge production and application, and able to serve the nation and the globe while also aspiring for to its own higher and longer-term visions (Li and Hayhoe 2013).

Concern has been expressed that the distinctive cultural frameworks of different localities should not be surrendered to the homogeneity of international standardization in the pursuit of achieving world-class higher education (Niland 2000). In this sense, the successful rise of the Chinese University 3.0 will depend on its capacity to balance its cultural heritage with the need to enhance quality and renew the institution as it seeks to meet new societal demands, locally, regionally, and globally. More important, the Chinese University 3.0 
should never forget its soul, in what might be described as a democratic mission rooted in the classical Confucian tradition ultimately for the highest individual and public good. One Western scholar has put it in a different but equally appealing way: "Education should never become an assembly line. Once it does, you may have a certain level of production, but you will never get the volume of creative thinkers that make democratic society work" (Simmons 2003, p. x).

China's Blueprint for Educational Reform and Development 2010-2020 (State Council 2010) and its new Master Promotion Plan of Building World-class Universities and Disciplines (State Council, 2015) both carry forward the ambition to build WCUs, and these drives have created WCUs in China. In 2015 scholars in the Mainland have started to win Nobel Prizes (Youyou Tu - Facts, 2015), and it will be foreseeable that in the next few decades China will become a research superpower and can boast of sustainable WCUs in the sense of globally recognized excellence in teaching and learning, knowledge exploration, sociopolitical actions, and governance. In her lecture on December $7^{\text {th }} 2015$, Youyou Tu has indicated that the traditional Chinese medicine is a gift to the world (Youyou Tu - Nobel Lecture, 2015). Similarly, when China has proven itself a successful model of development in many areas, not only its economy, the Chinese University 3.0 may also emerge as a gift to the world, a renewed model capable of setting new global examples for world-class higher education that may be appropriate to the needs of the later $21^{\text {st }}$ century. While some still doubt that Asian universities are based on their own heritages (Altbach 1992), the Chinese University 3.0 is exceptional, and it reflects key characteristics of China's indigenous scholarly tradition.

It is widely recognized that European universities and the immediate products of their activity constituted one of the great intellectual achievements of the Middle Ages (Rashdall 1895). Even though the emerging Chinese University 3.0 is still far from achieving worldclass standing, its rise is likely to constitute another great achievement of human history, together with the various models developed in the Western world and other parts of the globe. It is yet to be seen how its core features of self-mastery and intellectual freedom, in addition to socio-political mission and institutional diversity, will serve to foster vibrant, alternative societal development and contribute to a global dialogue among civilizations in the future. However a look back at China's significant contributions to human development over the lengthy historical period that preceded Europe's Scientific Revolution starting in the $16^{\text {th }}$ century, as shown by Joseph Needham (1954), provides a sense of hope and anticipation.

\section{Acknowledgements}

This chapter reflects on my long-time interest in the studies of Confucianism and Chinese universities and on my ongoing research projects on "China-Africa University Partnerships in Education and Training: Students, Trainees, Teachers and Researchers" funded by the Hong Kong Research Grants Council General Research Fund (RGC/GRF Ref.: CUHK842912) and "World-class Universities, Publication and Research Assessment: Rethinking the Mission of Higher Education in the Global Age" funded by the Research Development Fund of Worldwide Universities Networks (RDF/WUN Ref.: 4930217). Further reflections are available from my monographs Xuan Ru Fo Dao Jiaoyu Lilun Bijiao Yanjiu (A Comparative Study of Educational Theories of the Schools of Metaphysics, Confucianism, Buddhism and Taoism) (Wenjin Press, 1994), Jiaoyuxue Zhi (A History of Chinese Thought on Education) (Shanghai People's Press, 1998) and Quest for World-Class Teacher Education? A Multiperspectival Approach on the Chinese Model of Policy Implementation (Springer, 2016). With this opportunity, I thank very much the anonymous 
reviewers for their constructive feedback for the revision of the manuscript. I bear sole responsibility for its contents, however.

\section{References}

Altbach, P. G. (1992). Patterns in higher education development: Toward the year 2000. In R. F. Arnove, P. G. Altbach, \& G. P. Kelly (Eds.), Emergent issues in education: Comparative perspectives (pp. 39-55). Albany, NY: SUNY Press.

Altbach, P. G., \& Selvaratnam, V. (1989). From dependence to autonomy: The development of Asian universities. Dordrecht, Netherlands: Kluwer.

Chai, C., \& Chai, W. (1965, trans. \& eds.). The humanist way in ancient China: Essential works of Confucianism. New York: Bantam Books, Inc.

Chen, J. P. (1990). Confucius as teacher: Philosophy of Confucius with special reference to its educational implications. Beijing: Foreign Languages Press.

Ch'ien, M. (1943). Lixiang de daxue [The ideal of the university]. In the Editorial Board (ed.), Qian Binsi xiansheng quanji [The complete works of Mr. Qian Binsi] (vol. 41, pp. 205-215). Taipei: Linking Publishing.

Clark, B. (1983). The higher education system: Academic organization in cross-national perspective. Berkeley: University of California Press.

Ding, X. L. (2004). Shime shi shijie yiliu daxue [On university reform and development]. Beijing: Peking University Press.

Ding, X. L. (2001). Shime shi shijie yiliu daxue [What are the world-class universities]. Gaodeng Jiaoyu Yanjiu [Journal of Higher Education]. 22(3), 4-9.

Elman, B. (2000). A cultural history of civil examinations in late imperial China. Berkeley, CA: University of California Press.

Gao, S. L. (2005). Xueji yanjiu [A study of Xueji]. Beijing: People's Education Press.

Gao, S. L. (1982). Xueji pingzhu [An annotation of Xueji]. Beijing: People's Education Press.

Hanban. (n.d.). About Confucius Institutes and Classrooms. Retrieved January 7, 2016, from the Hanban Web Page: http://www.hanban.edu.cn/confuciousinstitutes/node 10961.htm

Hayhoe, R. (2001). Lessons from the Chinese academy. In R. Hayhoe \& J. Pan (Eds.), Knowledge across cultures: A contribution to the dialogue among civilizations (pp. 323-347). Hong Kong: CERC.

Hayhoe, R. (1996). China's universities 1895-1995: A century of cultural conflict. New York: Garland Press.

Hayhoe, R., \& Li, J. (2012). Institutional diversity in Chinese higher education. International Higher Education, 66, 22-24.

Hayhoe, R., \& Li, J. (2010). The idea of a normal university in the 21 st century. Frontiers of Education in China, 5(1), 74-103.

Hayhoe, R., Li, J., Chen, M., Zhou, G. L. (2011). Huazhong University of Science and Technology - A microcosm of new China's higher education. In R. Hayhoe, J. Li, J., Lin \& Q. Zha, Portraits of 21st century Chinese universities: In the move to mass higher education (pp. 307-343). Dordrecht and Hong Kong: Springer/CERC.

Hayhoe, R., Li, J., Lin, J., \& Zha, Q. (2011). Portraits of 21st century Chinese universities: In the move to mass higher education. Dordrecht and Hong Kong: Springer/CERC.

Hayhoe, R., \& Zhong, N. (2001). University autonomy and civil society in modern China. In G. Peterson, R. Hayhoe \& Y. Lu (Eds.), Education, culture and identity in $20^{\text {th }}$ century China (pp. 265-296). Ann Arbor, MI: University of Michigan Press.

Huntington, S., (1991). Democracy's third wave. Journal of Democracy, 2(2), 12-34. 
Jaeger, C. S. (2000). The envy of angels: Cathedral Schools and social ideals in medieval Europe, 950-1200. Philadelphia, PA: University of Pennsylvania Press.

Jiang, Z. M. (1998). Zai qingzhu Beijing daxue jianxiao yibai zhounian dahui shang de jianghua [Keynote speech at the centennial ceremony of Peking University]. Zhongguo Gaojiao Yanjiu [China Higher Education Research], 3, 3-5.

Kaneko, M. (2009). Incorporation of national universities in Japan: Design, implementation and consequences. Asia-Pacific Education Review, 10, $59-67$.

Kerr, C. (1963). The uses of the university. Cambridge, MA: Harvard University Press.

Lenzen, D. (2015). University of the world: A case for a world university system. Cham: Springer International Publishing.

Li, J. (2016a). Universities in the global research assessment movement: Comparative case studies in China, Hong Kong and Japan. In M. Ishikawa (Ed.), The world university rankings and international indicators of excellence reexamined. Kyoto: Kyoto University Press.

Li, J. (2016b). Quest for world-class teacher education? A multiperspectival approach on the Chinese model of policy implementation. Singapore: Springer.

Li, J. (2015). When Confucianism meets Ubuntu: Rediscovering justice, morality and practicality for education and development. International Journal of Comparative Education and Development, 17(1), 38-45.

Li, J. (2014). Christianity and education in Asia. In F. Wilfred (Ed.), The Oxford Handbook of Christianity in Asia (pp. 315-326). Oxford, UK: Oxford University Press.

Li, J. (2012). World-class higher education and the emerging Chinese model of the university. Prospects: Quarterly Review of Comparative Education, 42(3), 319-339.

Li, J. (2009). Confucianism. In D. Fong (Ed.), Encyclopedia of modern China (Vol. 1, pp. 347-351). New York: Scribner's.

Li, J. (1998). Jiaoyuxue zhi [A history of Chinese thought on education]. Shanghai: Shanghai People's Press.

Li, J. (1994). Xuan Ru Fo Dao jiaoyu lilun bijiao yanjiu [A comparative study of educational theories of the schools of Metaphysics, Confucianism, Buddhism and Taoism]. Taipei, Taiwan: Wenjin Press.

Li, J. (1988). Jixiaxuegong de banxue tedian jiqi xianshi qishi [Features of the Jixia Academy and its modern implications]. Gaodeng Jiaoyu Yanjiu [Journal of Higher Education], 34, 100-105.

Li, J., \& Hayhoe, R. (2013, Apr. 18). Goujian daxue de Zhongguo moshi 3.0 [The Construction of Chinese University 3.0]. Shehui Kexue Bao [Social Sciences Weekly]. No. 1358, 5. Retrieved February 26, 2015, from: http://www.shekebao.com.cn/shekebao/2012skb/xs/userobject1ai5707.html

Li, J., \& Hayhoe, R. (2012). Confucianism and higher education. In J. A. Banks (Ed.), Encyclopedia of diversity in education (Vol. 1, pp. 443-446). Thousand Oaks, CA Sage.

Li, J., \& Tian, X. H. (2015). A global internationalization experiment of Chinese Universities: Models, experiences, challenges and prospects of Confucius Institutes' first decade. Zhongguo Gaojiao Yanjiu [China Higher Education Research]. 260(4), 37-43.

Li, G. J., Wang, B. Z., \& Li, C. D. (1994). Zhongguo Shuyuan shi [A history of Chinese Shuyuan]. Changsha: Hunan Education Press.

Liu, L., \& Liu, N. C. (2009). Bibliometric Analysis of SSCI Publications of China From 1978-2007. Information Science, 27 (10), 1590-1594.

Lutz, J. (1971). China and the Christian colleges, 1850-1950. Ithaca: Cornell University 
Press.

Marginson, S. (2013). Emerging higher education in the post-Confucian heritage zone. In D. Araya \& P. Marber (Eds.), Higher education in the global age: Education policy, practice and promise in emerging societies (pp. 89-112). New York, NY: Routledge.

Marginson, S. (2011). Higher education in East Asia and Singapore: Rise of the Confucian Model. Higher Education, 61(5), 587-611.

Neave, G. (2001). The European dimension in higher education: An excursion into the modern use of historical analogues. In J. Huisman, P. Maassen, \& G. Neave (Eds.), Higher education and the nation state: The international dimension of higher education (pp. 13-72). Oxford: Pergamon.

Needham, J. (1954). Science and civilisation in China (vol. 1). Cambridge: Cambridge University Press.

Newman, J. H. (1859), The idea of a university. London: Longmans, Green, \& Co. (1907, originally published in 1852).

Niland, J. (2000). The challenge of building world class universities in the Asian region. ON LINE Opinion (February 3). http://www.onlineopinion.com.au/view.asp?article=997.

Pan, W. (Ed.) (2009). Zhongguo muoshi: Jiedu zhonghua renmin gongheguo de liushi nian [China model: A new developmental model from the sixty years of the People's Republic] Beijing: Central Compilation \& Translation Press.

Petracca, M. P., \& Xiong, M. (1990). The concept of Chinese neo-authoritarianism: An exploration and democratic critique. Asian Survey, 30(11), 1099-1117.

Ramo, J. C. (2004). The Beijing consensus. London: The Foreign Policy Centre.

Rashdall, H. (1895). The universities of Europe in the Middle Ages (vols. 1-3). Oxford: Oxford University Press.

Ritzer, G. (2003). The globalization of nothing. SAIS Review, 23(2), 189-200.

Rhoads, R. A., Wang, X. Y., Shi, X. G., \& Chang, Y. C. (2014). China's rising research universities: A new era of global ambition. Baltimore, MD: Johns Hopkins University Press.

Shi, Y. G., \& Rao, Y. (2010). China's research culture. Science, 329(5996), 1128.

Simmons, R. (2003, January 18). Striving for excellence: How to make a world-class university. South China Morning Post, p. 15.

Sun, P. Q. (2009). Zhongguo jiaoyu shi [A history of China's education] ( $\left.3^{\text {rd }} \mathrm{ed}.\right)$. Shanghai: East China Normal University Press.

The Analects of Confucius. (n.d.). Retrieved July 30, 2015, from: http://www.confucius.org/lunyu/lange.htm

The Doctrine of the Mean. (n.d.). Retrieved July 30, 2015, from: http://www.acmuller.net/con-dao/docofmean.html

The Editorial Board of the People's Republic of China Yearbook. (1999). 1999 Zhonghua renmin gongheguo nianjian [People's Republic of China Yearbook 1999]. Beijing: People's Republic of China Yearbook Press.

The Great Learning. (n.d.). Retrieved February 26, 2015, from: http://www.acmuller.net/con-dao/greatlearning.html

The MOE. (2014). 2013 nian quanguo jiaoyu shiye fazhan tongji gongbao [The national statistical communiqué of educational development 2013]. Retrieved February 26, 2015, from the MOE Web Site: http://www.moe.gov.cn/publicfiles/business/htmlfiles/moe/moe_335/index.html

The MOE. (1998, December 24). Mianxiang 21 shiji jiaoyu zhengxing xingdong jihua [The action plan for educational revitalization facing the 21 st century]. Retrieved 
January 7, 2016, from the MOE Web Site:

http://www.moe.gov.cn/jyb_sjzl/moe_177/tnull_2487.html

The MOE. (1992). 1991 nian quanguo jiaoyu shiye fazhan tongji gongbao [The national statistical communiqué of educational development 1991]. Retrieved February 26, 2015, from the China Education and Research Network Web Site: http://www.edu.cn/20010823/207278.shtml

The State Council (2015, October 24). Tongchou tuijin shijie yiliu daxue he yiliu xueke jianshe zongti fangan [The master promotion plan of building world-class universities and disciplines]. Retrieved December 4, 2015, from the Central People's Government of the People's Republic of China Web Site: http://www.gov.cn/zhengce/content/2015-11/05/content_10269.htm

The State Council (2010, May 5). Guojia zhongchangqi jiaoyu gaige he fazhn guihua gangyao 2010-2020 [The National Guidelines for Mid-and Long-Term Educational Reform and Development 2010-2020]. Retrieved February 26, 2015, from the Central People's Government of the People's Republic of China Web Site: http://www.gov.cn/jrzg/2010-07/29/content_1667143.htm

The UNESCO. (2003, June 23-25). Synthesis report on trends and developments in higher education since the World Conference on Higher Education (1998-2003). Retrieved January 7, 2016, from the UNESCO Web Site: http://unesdoc.unesco.org/images/0014/001455/145529E.pdf

Twitchett, D., \& Faribank, J. K. (1986). The Cambridge history of China (vol. 1). New York: Cambridge University Press.

Wang, Y. M. (n.d., Rep. 1936). Wang Yangming quanji [The complete works of Wang Yangming] (vol. 1). Shanghai: Shijie Shuju [World Books].

Weber, M. (1948). The methodology of the social sciences (trans. \& eds. by E. A. Shils, \& H. A. Finch). New York: The Free Press.

Weidman, J. C., \& Enkhjargal, A. (2008). Corruption in higher education. In D. P. Baker \& A. W. Wiseman (Eds.), International perspectives on education and society: The worldwide transformation of higher education (pp. 63-88). Bingley, UK: JAI Press.

Wong, W. S. (1976). The Hsüeh Chi, an old Chinese document on education. History of Education Quarterly, 16 (2), 187-193.

$\mathrm{Xu}, \mathrm{D} .$, \& McEwan, H. (2016). Universal principles for teaching and learning: XuejJi in the 21st century. Albany, NY: SUNY Press.

Youyou Tu - Facts. (2015). Lists of Nobel Prizes and Laureates. Retrieved December 4, 2015, from http://www.nobelprize.org/nobel_prizes/medicine/laureates/2015/tufacts.html

Youyou Tu - Nobel Lecture. (2015). Discovery of Artemisinin - A gift from traditional Chinese medicine to the world. Retrieved December 7, 2015, from http://www.nobelprize.org/nobel_prizes/medicine/laureates/2015/tu-lecture.html

Yu, Y. S. (1974). Wei xinya jingshen jinyi xinjie [A new interpretation of the Spirit of New Asia College]. New Asia Life Monthly, 1, 11. Retrieved December 12, 2014, from http://history.na.cuhk.edu.hk/Portals/2/Images/content/5-1_7.pdf 